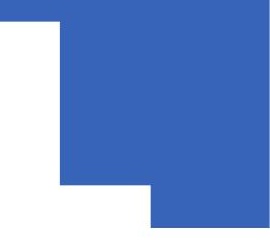

Family ownership, Workplace Closure and the Recession

Alex Bryson

Harald Dale-Olsen

Trygve Gulbrandsen

Department of Social Science

Working Paper No. 16-06

April 2016 


\section{Disclaimer}

Any opinions expressed here are those of the author(s) and not those of the UCL Institute of Education. Research published in this series may include views on policy, but the institute itself takes no institutional policy positions.

DSS Workings Papers often represent preliminary work and are circulated to encourage discussion. Citation of such a paper should account for its provisional character. A revised version may be available directly from the author.

Department of Quantitative Social Science, UCL Institute of Education, University College London, 20 Bedford Way, London WC1H OAL, UK 


\title{
Family ownership, Workplace Closure and the Recession
}

\author{
Alex Bryson', Harald Dale-Olsen ${ }^{2}$ and Trygve Gulbrandsen ${ }^{3}$
}

\begin{abstract}
Using nationally representative Norwegian data we show family-owned workplaces are less likely to close than observationally similar non-familyowned workplaces. But this changed during the Crisis when the family businesses' closure hazard soared. This hike in 2009 was not related to performance or the observed capital structure. Whereas bad performance has a tendency to kill non-family businesses regardless of the equity level, a need for fresh capital has a tendency to kill family businesses regardless of performance. We conclude that family firms suffered from a lack of credit during the Crisis, something that policy-makers should address before the next economic downturn.
\end{abstract}

JEL codes: G32, G34, J65

Keywords: Family ownership; Closure; Financial performance; Debt;

Leverage

Contact Details: Alex Bryson (a.bryson@ucl.ac.uk), UCL

Acknowledgements:

We thank participants at RES2016 in Brighton, COPE2015 in Vienna, EEA2015 in Mannheim, Erling Barth and participants at the Institute for Social Research's seminar series spring 2015 for comments and the Norwegian Research Council for funding (grant No. 173591/S20 and 202647/S20). Corresponding author: Harald Dale-Olsen, Institute for Social Research, e-mail: hdo@socialresearch.no

\footnotetext{
${ }^{1}$ University College London, National Institute of Social and Economic Research and Institute for the Study of Labor a.bryson@ucl.ac.uk

${ }^{2}$ Institute for Social Research, Oslo

${ }^{3}$ Institute for Social Research, Oslo
} 


\section{Introduction}

Many firms were adversely affected by the Great Recession, but some were more adversely affected than others. Research to date has focused on sectoral differences but in this paper we focus attention on the role of family ownership. Family businesses are an important feature of modern economies. In their study of roughly 5232 larger corporations, Faccio and Lang (2002) found that in 13 Western European countries the lowest share was reported in the UK (23.67 percent), Norway's share was just above 38 percent, while family businesses were in majority in the continental countries like France, Germany, Italy and Spain. Family firms are particularly vulnerable to economic downturns for several reasons. First, although the point is contested (see Section Two) they tend to be less productive than like businesses which are not under family control (Morck et al., 2000; Barth et al., 2005). Second, they are more poorly managed (Bloom and Van Reenen, 2007; Gulbrandsen, 2005, 2009) and so less able to respond appropriately to crises. Third, they tend to be more highly leveraged due to cheaper debt costs (Anderson et al., 2003), while constraints on equity financing arise from a perceived lack of transparency in family firms' accounting (Croci et al., 2011). This may have been particularly important in the Great Recession because the economic crisis led to credit shortage. According to Armstrong et al (2013:4) there was "a shortage of finance for SMEs [in the UK], reflecting banks' attitudes to risk and their own pressures to de-lever combined with banks' market power in the SME sector". In the US, $86 \%$ of surveyed CFOs said their investments in attractive projects were restricted during the 2008 crisis (Campello et al., 2010). If liquidity supply dried up during the financial crisis (Cornett et al., 2011) this may have had a detrimental impact on the survival of family businesses compared to other businesses. Literature on family firm survival is scarce. For the UK Wilson et al. (2013) found that family firms were less likely to close than non-family businesses in the period 2007-10, but they did not investigate the potential differential effect of the financial crisis on the survival of family versus non-family firms.

In this paper we focus on Norway where bank lending declined in 2009, recovering subsequently (Figure 1). ${ }^{4}$ Lending to new businesses had started to fall in 2007 (Hetland and Mjøs, 2014). The decline in lending coincided with a massive increase in workplace closure rates and bankruptcies (Figure 1 ).

[INSERT FIGURE 1]

\footnotetext{
${ }^{4}$ In their yearly report for 2010, The Norwegian Financial Authority reports that lending growth for Norwegian banks dropped from $20 \%$ in late 2008 to $-5 \%$ in early 2010. For foreign owned bank affiliates in Norway, the drop was even greater: from $50 \%$ in late 2008 to $-20 \%$ early 2010 .
} 
Family-owned businesses are often smaller than non-family-businesses so may be more credit-constrained, potentially increasing their risk of closure during a downturn. On the other hand, if the owners of family businesses have psychic income from entrepreneurship, face poorer alternative employment opportunities, or higher costs of switching to other occupations, then their owners may choose to keep their family businesses running and thus survive despite comparatively low performance (Gimeno et al., 1997). They may also display a loyalty to 'their' staff that is less common among other firms (Demsetz and Lehn, 1985; James, 1999; Burkart et al., 2003; Bertrand and Schoar, 2006), perhaps altering the threshold at which they consider closure as an option.

We contribute to the literature by examining the determinants of workplace closure among family-owned and non-family-owned workplaces pre- and post-recession identifying the role played by firms' financial performance and debt acquisition. Our analyses link these workplace data to employees and their jobs, and to firm-level accounting data.

The structure of the paper is as follows. Section 2 discusses the nature of family owned firms in Norway and the theory and empirical findings relevant for our study. Data is described in Section 3. Section 4 presents the econometric strategy. In Section 5 we study family ownership and management and closures empirically. Section 6 concludes and discusses the policy implications.

\section{Family ownership, management and liquidity constraints}

There is no a priori theoretical reason why family firms are necessarily less productive than other firms. Indeed, Bertrand and Schoar (2006) list several arguments as to why family firms may perform better than other firms, including the minimisation of principal-agent problems. Concentrated ownership may have advantages over dispersed ownership in terms of better monitoring of day to day operations of the firm (Burkart et al, 2003), leading family firms to be more productive than non-family firms. Some studies find positive effects of family ownership on productivity and performance (Berzins and Bøhren, 2013). Anderson and Reeb (2003) conclude that on average family firms actually perform better than non-family firms, although their performance drops rapidly when families control more than 50 percent of the shares. On the other hand, once one deals with selection into family ownership, then their poorer productivity (Barth et al., 2005) and poorer management became apparent (Bloom and Van Reenen, 2007).

An optimal supply of capital is crucial for maximising profits. ${ }^{5}$ However, credit rationing can arise in markets with frictions (Stiglitz and Weiss, 1981; Evans and Jovanovich, 1989). Recessions curb firms' investments due to reduced availability of bank credit and

\footnotetext{
${ }^{5}$ Cagetti and De Nardi (2006) show that at the aggregate level such borrowing constraints generate less wealth concentration, reduce average firm size and the fraction of entrepreneurs.
} 
alternative sources of finance (Gaiotti, 2013). ${ }^{6}$ Thus if entrepreneurs cannot borrow or will not borrow to attain their profit-maximising levels of capital, then entrepreneurs having more personal assets will profit more. Holtz-Eakin et al.'s (1994) empirical evidence for the US supports this notion, although their sample of high pre-inheritance income entrepreneurs make them unable to draw inferences regarding the survival of a typical new venture. Hvide and Møen (2010) identify a positive relationship between founder prior wealth and start-up size among Norwegian entrepreneurs, but profitability on assets drops sharply in the upper quartile of the founder wealth distribution, thus indicating slack.

Family firms generally avoid risk (e.g., Agrawal and Nagarajan, 1990; Hiebl, 2013), although Mishra and McConaughy (1999) find this tendency is confined to family firms still owned and run by the founding family. Since debt might imply higher risk, one might therefore think that family firms avoid debt. However, Bopaiah (1998) argues that family businesses might be seen by lenders as having fewer moral hazard problems than nonfamily businesses (since these often are more widely held) and find empirical support for the notion that family businesses are associated with wider availability of credit. Similarly, Anderson et al. (2003) argue that debt financing might be cheaper for family firms due to lower agency costs and find empirical evidence for this notion. Cheaper debt financing thus imply less equity and more debt. On the other hand, Danes and co-authors argue that social and human capital is more important for family businesses than financial capital, since the latter might be constrained (Danes et al., 2009; Danes and Brewton, 2012). Finally, one should be aware of differences related to management. Lyangoubi (2006) stresses that when family firms introduce professional management (i.e., a hired CEO), this induces a higher level of free cash flow risk, which then again manifest in professionally managed family firms being more indebted than family-managed family firms (as is seen in her empirical study).

Even when families allow stocks and shares to be sold to external investors to raise finance, they often desire a high degree of control. One way of achieving this is to issue stocks with different voting rights. Investors are free to purchase less influential stocks, thus allowing the family to stay in power. Such a strategy, however, may be detrimental to achieving the optimal supply of capital. Many investors make influence a precondition when investing in a firm. Furthermore, Gompers et al. (2003) have shown that an investment strategy which purchases shares in strong-shareholder rights firms and sells weak shareholder rights firms earns abnormal returns of 8.5 percent per year, i.e., there is a significant negative premium associated with investing in firms which eschew (minority) shareholder rights. Most investors want a high return on their investments, and thus such

\footnotetext{
${ }^{6}$ Gaiotti (2013) argued that in other periods the availability of bank credit matters less due to the ability to tap alternative sources of finance. Empirically he found that during the global crisis the impact of credit quantity constraints on Italian investment in manufacturing was significant.
} 
negative premiums could reduce family businesses' probability of achieving the desired external supply of capital, thus making them more prone to liquidity constraints. If this is the case, family-owned businesses are more likely to run at a sub-optimal level of capital and thus under-perform which, in turn, makes them attractive targets for takeovers and acquisitions.

\subsection{A simple model of exit and ownership change}

To assess the effects of family ownership on exit we consider a simple dynamic model of entry and exit of firms outlined by Dunne et al. (2013). Assume that firms must incur a fixed cost, $\lambda$, prior to production. $\lambda$ is private information drawn from a known distribution every period. The expected value of a continuing firm may be written as:

$$
\text { 1) } \quad \mathrm{V}(\mathrm{s} ; \lambda, \mathrm{Y})=\pi(\mathrm{s}, \mathrm{Y})+\max \{\delta(\mathrm{VC}(\mathrm{s}, \mathrm{Y})-\lambda), 0\}
$$

where the first part is current profits, and the second part is the option value of continuing production in the next period. $s$ is a state variable, $y$ a productivity shifter, VC is the expected value of the firm in the next period. If $V C<\lambda$, the firm exits. The probability of exit is then given by $p=\operatorname{Pr}(\lambda>V C)$, and the value of a continuing firm may be written as:

$$
\text { 2) } \quad V(s ; \lambda, \gamma)=\pi(s, \gamma)+\delta(1-p)\left[V C(s, y)-\lambda^{*}\right]
$$

where $\lambda^{*}$ is the expected fixed cost conditional on continuation. Family ownership may enter this equation in two ways. First it may enter the value of current production, either because of productivity differences, e., g., from enhanced monitoring, or because production may provide the family owner with some intrinsic value. Let $\mathrm{V}=1$ for non-family firms and $\mathrm{Y}^{\dagger}$ for family firms, indicating a shifter in the current value of profits. Comparing a family firm to a non-family firm thus means comparing different values of current profits and future expected profits. A higher value of profits implies a higher expected value of the firm in the next period as well, affecting the exit probability negatively. This will in turn increase the expected value of the firm in future periods, reducing the exit probability even further, and so on, until equation (2) is again in balance. The effect of a positive value of the profit shifter is thus to reduce the exit probability of family firms.

One way of raising capital to finance operation is by ownership dispersal, for example by issuing new shares. This might be opposed by current stakeholders and shareholders in any firm - family owned or not. However, family ownership may affect the possibility of obtaining necessary financing without dispersing ownership control. In particular, family firms are more likely to be credit constrained, and may, in the case of financial distress, be unable 
to raise capital on the loan marked to cover the fixed costs necessary to resume production in the next period. Assume that the family has own funds, F, to put up as collateral towards such a loan, and that available credit will be constrained to be less or equal to $\mathrm{cF}$. The value of the non-family firm is given by $(2)$, for $\mathrm{y}=1$, while the value of the continuing family firm is:

$$
\text { 3) } \quad V^{f}(s ; \lambda, \gamma)=\pi\left(s, Y^{f}\right)+\delta\left(1-p^{f}\right)\left[V C\left(s, Y^{f}\right)-\lambda^{\star}\right]
$$

where the probability of exit is now: $p^{f}=\operatorname{Pr}(\lambda>\min (\mathrm{VC}, \mathrm{cF}))$; i.e. the firm exits either if the fixed cost is above expected value of future production, or if it is higher than the credit constraint. We notice two things. First, credit constraints immediately increase the probability of exit by lowering the bar for fixed costs that the firm can possibly cover. Second, increased probability of exit lowers the expected value of the continuing firm, adding to the negative effect on the exit probability. And so on, until again equation (3) is satisfied. We also note that the strength of this effect depends on the value of the firm's own financial position. Furthermore, this effect is higher the more demanding the pre-production fixed cost requirements are. For this reason, capital constrained firms will undertake inefficiently small capital investments (Holtz-Eakin et al., 1994). Finally, when the financial crisis caused banks to become more risk averse while de-leveraging, this enters the model as a lowered parameter c, i.e., as if the funds of the family drop in value as collateral.

We thus have two conflicting hypotheses. The probability of exit may be lower for family owned firms, because owners may be more efficient or simply have a willingness to pay for keeping the firm open. Alternatively, capital constraints may keep them from undertaking necessary investments to stay in business, and this might have been enforced during the financial crisis. In the empirical section, we investigate to what extent the probability of exit differs between the two types of ownership, and to what extent the probability is sensitive to management regime and to the firm being in financial distress.

\section{Data}

We utilise the Norwegian Workplace Employment Relations Survey (NWERS) 2003 which provides large-scale, statistically reliable data on industrial relations and employment practices across most sectors of the Norwegian economy. The level of observation is the workplace, namely a place of employment at a single address or site (in contrast to a firm, which is an legal unit, which might be located several places). The survey comprises a stratified random sample of workplaces in Norway with at least 10 employees. Data were collected through a face-to-face interview with the senior manager responsible for employment relations on a day-to-day basis. In total 2358 interviews were conducted for the 
2003 survey with response rates of 77 percent respectively. Since our topic is family ownership and the relationship to financial performance and debt, we naturally exclude public sector employers, leaving us with 1404 workplaces for 2003.

The surveys are linked to Norwegian public administrative register data comprising all workplaces, firms and their employees in Norway 1995-2013 (roughly 140000 firms, 180000 workplaces and 2000000 employees each year). These linked employer-employee data provide detailed information on workers and accounting data. ${ }^{7}$ Because some firms are not required to submit accounting data, e.g. liable companies, our final data set consists of 1100 workplaces in 2003. These workplaces are owned by limited (stock-based) companies, i.e., companies where the owners have limited liability, and where the law requires the firms to have at least 30000 NOK (=£2500) in own capital. No requirement exists demanding that the stocks of these companies should be freely tradable on a market.

Workplace closure is defined as the complete cessation of worker related activities of a workplace with the termination of all contracts of employment. ${ }^{8}$ The transfer of employment to a new site or to another workplace in the same organization is not included in this definition, nor is a simple change of ownership such as a take-over. Note that firms and workplaces are identified by different number series. Thus mergers and acquisitions would affect the firm identifier, but not the workplace identifying number series (as described above, the workplace is a local unit). Family ownership, family-manager and professional manager are dummies constructed from questions in the questionnaire. The questions are as follows: 1)According to the business register, the firm owning this workplace is a singleworkplace firm and is organized as a joint stock company. Is $50 \%$ or more owned by a family or individual? 2) According to the business register, this workplace is owned by a firm owning multiple workplaces, but the firm is organized as a joint stock company. Is $50 \%$ or more owned by a family or individual? Next, these two questions are repeated for those firms which are organized as a responsible (fully or partly) company. Finally, if the workplace is family-controlled, a question on managing is asked as follows: Is the daily manager a member of the controlling family?

From the accounting data we construct several measures expressing performance and financial structure: return on assets $(R O A)$, equity rate $(E R)$ (equity relative to debt and equity), debt-to-equity ratio, current assets-to-debt, and dummies for whether the firm experiences operating loss and negative shareholders' equity. To limit potential measurement error accounting measures are winzorised at the 5/95 percent level.

\footnotetext{
${ }^{7}$ If a firm is missing for a year in the accounting data but appears for several years before and after, we impute the missing value based on the year before. This affects $3 \%$ of the observations.

${ }^{8}$ This results in the disappearance of the workplace ID from the administrative registers of the public social services and tax authorities.
} 
We create a panel dataset based on the NWERS2003 population which we then follow over time to closure (after 2003) or to censoring (in 2013). Of the panel workplaces only 4 workplaces leave family control during the next 10 years thus making fixed effects estimation infeasible.

\section{Econometric strategy}

The focus of our empirical investigation is a survival analysis to establish closure probabilities for family and non-family firms in the period 2003-2013. But before that we examine the financial status of family and non-family firms at the start of the period in 2003 . We consider whether the two types of firm differ significantly in terms of returns on assets (ROA), net loss, equity, negative shareholders' equity, debt-to-equity ratio, and current assets-to-debt.

The survival analysis uses annual workplace panel data so that a discrete-time duration analysis framework is appropriate. Assume that $T_{i}$ expresses a continuous nonnegative random variable measuring workplace i's survival time. We observe whether a workplace in a given time interval $\left[t_{k}, t_{k+1}\right.$ )(defined by the year), $k=1$,., $k_{\max }$, and $t_{1}=0$, has closed conditional on the workplace's survival up to the beginning of the interval and given the explanatory variables in the model. In other words, we observe workplace i's spell from year $k=1$ through to the end of the jth year (max), at which point i's spell is either complete, or right censored. The last year in existence is 2012 , which then measures potential closure in 2013. The discrete-time hazard rate can be defined as:

$$
h_{i k}=P\left(T_{i}<t_{k+1} \mid T_{i} \geq t_{k}, X_{i k}\right)=F\left(X_{i k}{ }^{\prime} \beta+\gamma_{k}\right) \text {, }
$$

where $X_{i k}$ is a vector of time-fixed and time-varying covariates, $\gamma_{k}$ is a vector of year and 6 time interval dummies allowing a quasi-non-parametric modeling of the baseline hazard (piece-wise constant), $\mathrm{F}$ expresses the complementary log-logistic distribution function ensuring that $\quad 0 \leq h_{i k} \leq 1$ for all $i ; k$. The log likelihood can similarly be expressed as:

$$
L n L=\sum \sum\left[y_{i k} \ln \left(h_{i k}\right)+\left(1-y_{i k}\right) \ln \left(1-h_{i k}\right)\right]
$$

where $y_{\mathrm{ik}}$ expresses a binary indicator variable $y_{\mathrm{ik}}=1$ if workplace i makes a transition (their spell ends) in year $\mathrm{k}$ by being observed as closed in year $\mathrm{k}$, and $\mathrm{y}_{\mathrm{ik}}=0$ otherwise.

Note that in the expressions above we have not incorporated unobserved heterogeneity (frailties). One might think that by assuming a parametric distribution for the unobserved heterogeneity this could be easily incorporated into the set-up above. However, due to NWERS2003 being a stock sample, this oversamples survivors (and thus older workplaces), which thus biases the approach above.

In the empirical duration analyses we let the $X_{i k}$-vector comprise different time-fixed and time-varying covariates. Our main interest is the differential effect of the financial crisis of $2008 / 9$ on workplace survival for family and non-family workplaces. Thus key variables are a 
dummy for young family businesses less than 6 years old $\left(F Y_{i}\right)$, a dummy expressing family businesses with workplace age $>6$ years $\left(F_{i t}\right)$ (only these "old" businesses could face the crisis, since NWERS2003-workplaces could have been established no later than 2002), and

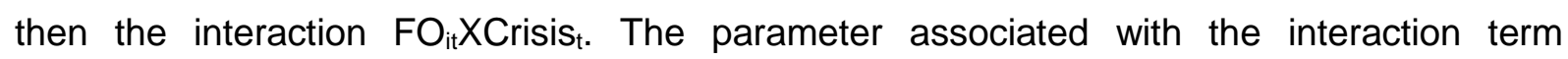
expresses whether family businesses are particularly hard hit by the financial crisis compared to other businesses. We then add controls in a "kill-the-coefficient approach" and see whether this relationship is sensitive to performance and debt structure.

\section{Family ownership, family management and closures}

Table 1 presents descriptive statistics on the incidence of family-owned and other firms prior to the Crisis in 2003 (Panel A) and shows closure rates, debt and financial performance among family and non-family firms (Panel B).

Six points are noteworthy. First, family ownership is common in Norway, accounting for one-half of private sector workplaces with 10 or more employees. This rate is slightly higher than what Faccio and Lang (2002) found for Norway, but they focused on larger corporations and we focus on workplaces. Second, six-in-ten of these family firms (61\%) are family-managed in 2003. Third, on average, from 2003 to 2012 family-owned businesses were more likely to close than other businesses ( $89 \%$ versus $80 \%$ )(the annualised closure rates in this period is slightly higher than for the period 1997-2003). This is in line with Wilson et al. (2013) who also observed lower closure rates for family firms. Fourth, in 2003 family businesses appear to perform better than non-family businesses, thus supporting the previous findings of Berzins and Bøhren (2013) for Norway. Fifth, family businesses carried more debt and less equity than non-family businesses pre-Crisis, i.e., in line with the notion that family firms prefer debt to equity financing. The debt-to-equity ratio is 4.1 in 2003 for family businesses, but only 2.4 for non-family businesses. On the other hand, this runs counter to the previous literature regarding family management and debt, which finds founder-family-managed firms avoid (forced or involuntarily by lack of collateral) debtfinancing. On the other hand, when $50 \%$ of the workplaces are family-owned as in Norway, they are less likely to be founding-family controlled. ${ }^{9}$

\section{[ Table 1 around here ]}

\footnotetext{
9 When a similar survey as NWERS 2003 was conducted in 2012 comprising information on founders, this revealed that close to 28 percent of the family-controlled workplaces were managed by the founder. Similarly, in close to 50 percent of the cases, when the workplace is family-controlled and managed by someone from the controlling family, this is the founder.
} 
Whenever costs surpass revenues, the resulting loss has to be covered - either by savings and own capital or by acquiring debt. However, debt is also a success indicator, given that high debt firms have actually been evaluated by creditors and achieved financing for their projects. Loans (and thus debt) are thus an ordinary and necessary component of doing business.

How leveraged a firm is has to be considered jointly with the anticipated risk and the expected return on capital. These factors vary strongly between industries, over time and over lifetime cycle (from start-up, to mature business, and closing stages). Thus the descriptive findings in Table 1, might be explained by family and non-family workplaces having different ages, being of different sizes and being involved in different industries. We therefore estimate Tobit- and Probit-regressions to establish how these key business dimensions are associated with being family-controlled or family-managed conditional on a wide set of controls. ${ }^{10}$ This provides a descriptive background for the duration analyses that follows. Table 2 presents the results.

\section{Table 2 around here ]}

Table 2 reveals that even after controlling for a wide set of controls family businesses experience higher return on assets (ROA) and lower loss probability than non-family businesses, but at the same time they are more leveraged and thus face more risk. Familymanaged businesses also appear to have less equity than other workplaces. ${ }^{11}$ Family and non-family businesses are equally likely to experience negative shareholders' capital.

How do these workplaces survive over time and how were they affected by the financial crisis? Figure 2 shows the yearly closure rates for family and non-family businesses of the 2003-workplace-population contingent upon survival to that year (hazard rates). It also shows closure rates for family-managed and professionally managed family businesses separately. Closures rose for both family and non-family workplaces during the Crisis, but the hike in closure hazards for the family workplaces is clearly much stronger for those that were professionally managed. However, this might reflect other differences between professionally managed family businesses and other family firms. For example, professionally managed family firms tend to be more mature and operate in different industries to those that are family managed. Therefore we estimate several discrete duration complementary log-log regressions modelling the closure hazards over time. The results are presented in Table 2.

[ Figure 2 around here ]

\footnotetext{
${ }^{10}$ Our control vector comprises dummies for listed, export, size (4), industry (40), product demand(2), age(5) (number of dummies in parentheses).

${ }^{11}$ Note that although the point estimates are not significant, they indicate that the higher returns and leveraging are related to family managing, which again probably will be related to many of these being run by the founder (see note 6). Thus these workplaces could be in a different phase of their life-cycle (e.g., being younger, newly-started).
} 


\section{[ Table 2 around here ]}

Model 1 incorporates six age interval dummies to model the duration dependency, dummies for being listed and being an exporter, as well as these two variables interacted with the 2009-dummy. It is well known that listed firms and exporters took a hit during the financial crisis due to reduced demand. The latter is not confirmed in the analysis, but workplaces of listed firms do close more frequently in 2009. The key parameter of interest, however, is the interaction term between family business with age over 6 years and 2009 (FOX2009). This is strongly significant, implying that family businesses experienced a strong hike in the closure hazards during the financial crisis. Relative to the baseline, this implies 2.9 times higher closure hazards in 2009.

Additional controls are incorporated in subsequent models. In Model 2 we add 4 workplace size dummies ( $<25,25-49,50-103,104-254$, reference $>254$ employees), 8 industry dummies (1-digit SIC-code), and 2 dummies for product demand characteristics (increasing demand and price-elastic demand). The interaction term becomes slightly weaker, but remains strongly significant.

In Model 3 we add dummies for whether the business is operating at a loss or if shareholders' capital has become negative (i.e., lost), and the corresponding interaction terms with family business. We see that operating at a loss is a predictor for business closure for non-family businesses, but not for family businesses. On the other hand, for family businesses negative shareholders' equity implies closure, but this does not matter for nonfamily businesses. ${ }^{12}$ Firms experiencing negative shareholders' capital are required to get additional funding (all limited firms are required to have at least $30000 \mathrm{NOK}$ ). This is easily achieved for non-family businesses, while these family businesses struggle. However, negative shareholders' equity is a warning sign of bad performance, thus this is as expected and not necessarily something that policy makers should seek to remedy. The key finding is that regardless of these performance measures, family businesses experience a hike in the closure hazard due to the financial crisis.

How strong is this impact? This is seen in Figures 3 and 4, which present the closure hazard rates and cumulative survival probabilities for 2008 and 2009 for family and nonfamily businesses. The rates are predicted for good performing workplaces (operating with no loss and having positive shareholders' equity) non-listed and non-exporting manufacturing workplaces with 250 employees, i.e., workplaces with lower hazards than an average workplace. However, focussing on smaller or more badly performing workplaces would not change the relative relationship between the hazards of 2008 and the hazards of 2009

\footnotetext{
${ }^{12}$ Negative equity is usually taken as a business warning signal, but might also occur when huge investments have been made, which might yield considerable profits in the future. Typically negative shareholders' equity is associated with intangibles amortization, debt funding, accrued liabilities and large dividends.
} 
(which is our focus), although both the hazard levels and the difference between family and non-family business would have been greater.

\section{[ Figure 3 around here ] \\ [ Figure 4 around here ]}

Figure 3 reveals a u-shaped development of the closure hazards over time. New entrants face high closure hazards, which diminish until middle age, only to increase again as the workplaces grow old. However, the main result is that while the hazards for non-family businesses are reduced by half from 2008 to 2009, they triple for family businesses. For the cumulative survival probabilities this implies that in 2008 family businesses were 20 percentage points more likely to reach 20 years than non-family businesses, in 2009 family businesses were 5 percentage points less likely to reach 20 years than non-family businesses. At older age this reversal has been even greater. Thus the financial crisis of 2009 was a major shock to these workplaces' survival.

In Model 4 we add return on assets and the equity rate, so we completely control for performance and the capital structure. While better performance (higher ROA) reduces the closure hazard, this has no qualitative impact on the previous estimates. So even conditional on performance and capital structure, we see that the financial crisis caused higher closure hazards for family businesses relative to non-family businesses.

Models 5-6 are further robustness checks. In Model 5 we add interaction terms between family businesses, and each of the years 2008, 2009, and 2010. We see that only the interaction term with 2009 remains strongly significant. In Model 6 we add a dummy for being family managed as well as the relevant interactions. We see that given our wide range of controls, family managed workplaces do not differ significantly from professionally managed family-owned workplaces, i.e., regardless of management, family businesses experience a closure hazard hike in 2009 compared to non-family businesses.

We also estimated models where we interact ROA, equity rate, the net loss dummy and the dummy for negative shareholders' equity with 2009. These interactions are usually non-significant, i.e., the impact on closures of ROA, equity rate, the net loss dummy and dummy for negative shareholders' equity do not change in 2009. This does not mean that ROA, equity rate, the net loss dummy and dummy for negative shareholders' equity do not change in 2009, only that their impacts do not change. Mostly, however, FOX2009 remains significant and positive. We have even studied ROA, equity and debt-to-equity by creating decile dummies for these measures. In that case, we see a differential impact for the uppermost decile in the debt-to-equity distribution, i.e., those being most leveraged face 
higher closure rates under the financial crisis. Still, the FOX2009 remains significantly positive.

We have also replaced the age measure based on register age with an age measure based on subjective questionnaire information. Register age is restricted to the time gone since the creation of the administrative register in the 1960s. Neither this does not change anything qualitatively.

Finally, in Model 7 we add interactions between net loss and the occurrence of negative shareholders' capital. We see that facing net loss and negative shareholders' equity is strongly indicative of closure for all businesses, but what is particularly important for family businesses is negative shareholders' equity. For non-family businesses it is operating losses that kill them.

\section{Conclusion and discussion}

Using Norwegian workplace data we have shown that, in general, family owned workplaces close less frequently than other workplaces, but this changed during the financial crisis. The Crisis caused a big hike in the closure hazard of family businesses in 2009 compared to nonfamily businesses. We have also shown that this hike in 2009 was not related to family firms' performance or observed capital structure that year. Excessively high debt was more detrimental to family businesses than to non-family businesses in 2009 compared to other years, but this captures only the impact of loans already supplied. Our findings persist even after controlling for this (not shown in the tables). Our explanation is that family businesses were more severely hit by the credit crunch than other businesses, i.e., they did not get necessary funding for sound projects and closed down. Lack of funding will not be directly visible in the accounting data. An alternative explanation is that family owners become excessively worried about losing the family fortune in 2009 and thus more risk averse (due to massive media coverage), and therefore closed down more frequently. Although we cannot reject this explanation outright, we argue that this is unlikely. First, choice of management reflects families' degrees of risk aversion and need for control (professional managers imply more risk and loss of control), but this does not matter for the closure hazard hike in 2009. Second, family owners of firms highly in debt would if closed down and liquidated, already have lost their family fortune and thus their closure hazards would not be affected by this worry. Thus we should have seen significant impacts of the 2009-dummy interacted with equity rate and dummy for negative shareholders' equity, and controlling for these interactions should have affected the closure hazard hike associated with family businesses in 2009. This we do not observe. Thus we conclude that family firms suffered from a lack of credit during the Crisis. 
During 2009 the obstacles to raising capital become issues for family businesses to a much larger extent than for other businesses. Whereas bad performance has a tendency to kill non-family businesses regardless of the level of shareholders' equity, negative shareholders' equity (and thus a need for fresh capital) has a tendency to kill family businesses regardless of performance.

What can we learn from our study, and what are the policy implications? Lower interest rates and increased government demand for products and services were policies used to lessen the burden for businesses in Norway during the financial crisis. This actually lowered the short-run closure hazards in 2009 for well-established workplaces (our workplaces facing the crisis were at least 7 years old), while the bankruptcy rate increased and overall the closure rate soared (younger workplaces took a hit). However, in 2009 financially sound family businesses died, implying lost business opportunities. And for these businesses access to capital should have been made easier. So next time a recession hits and a debt crisis unfold, public policy makers should take care to ensure that loans are available for profitable businesses.

\section{References}

Agrawal, A. and N. J. Nagarajan (1990). "Corporate Structure, Agency Costs, and Ownership Control: The Case of All-Equity Firms." Journal of Finance, 45: 1325 - 1331.

Anderson, R., Mansi, S. A., and Reeb, D. (2003),."Founding family ownership and the agency cost of debt," Journal of Financial Economics, 68, 263-285.

Anderson, R. C. and D. M. Reeb (2003). "Founding-family Ownership and Firm Performance: Evidence from the S\&P 500." Journal of Finance, 58: 1301-1328.

Angelini, P. R. Di Salvo, and G. Ferri (1998), "Avilability and Cost of Credit for Small Businesses: Customer Relationships and Credit Cooperatives,» Journal of Banking and Finance, 22, $925-954$.

Angeloni, I., A. Kashyap, and B. Mojon (2003)(eds.), Monetary Policy Transmission in the Euro Area. Cambridge:Cambridge University Press.

Armstrong, A., E. Phillip Davis, I. ladze, and C. Rienzo (2013), Evaluating Changes in Bank Lending to UK SMEs over 2001-12 - Ongoing Tight Credit? Department for Innovation, Business and Skills.

Asiedu E., J. Freeman, and A. Nti-Addae (2012), "Access to Credit by Small Businesses: How Relevant Are Race, Ethnicity, and Gender?" American Economic Review, 102, 532-537.

Bank of England (2012), "Trends in lending, January 2012”, Bank of England, London.

Barth, E., T. Gulbrandsen, and P. Schøne (2005). "Family-ownership and productivity: The role of owner-management." Journal of Corporate Finance, 11: 107 - 127.

Bertrand, M. and A. Schoar (2006), "The role of family in family firms," Journal of Economic Perspective, 20, $73-96$.

Berzins, J. and $\varnothing$. Bøhren (2013), "Norske familiebedrifter: Omfang, eierstyring og lønnsomhet", Praktisk økonomi og finans, 3, 58 - 73.

Bloom, N. and J. Van Reenen (2007). "Measuring and explaining management practices across firms and countries." Quarterly Journal of Economics, 122: 1351 - 1408.

Bopaiah, C. (1998), "Availability of Credit to Family Businesses," Small Business Economics, $11,75-86$. 
Bontempi, M. E., R. Golinelli, and G. Parigi (2010), "Why Demand Uncertainty Curbs Investments: Evidence from a Panel of Italian Manufacturing Firms," Journal of Macroeconomics, 32, $218-238$.

Bordo, M. D. and J. G. Habrich (2009), Credit Crisis, Money and Contractions: An Historical View," Journal of Monetary Economics, 57, 1- 18.

Burkart, M., F. Panunzi and A. Shleifer (2003). Family Firms." Journal of Finance, 58: 2167 2201.

Cagetti, M. and M. De Nardi (2006). "Entrepreneurship, Frictions and Wealth." Journal of Political Economy, 114: 835 - 870.

Campello, M., J. Graham, and C. Harvey (2010), "The real effects of financial constraints, evidence from a financial crisis", Journal of Financial Economics, 97, 470-487.

Claessens, S., S. Djankov, J. P. H. Fan, and L.H.P. Lang (2002). "Disentangling the Incentive and Entrenchment Effect of Large Shareholdings." Journal of Finance, 57: $2741-2771$.

Cornett, M. M., J.J. McNutt, P. E. Strahan, and H. Tehranian (2011), "Liquidity risk management and credit supply in the financial crisis", Journal of Financial Economics, $101,297-312$.

Croci, E., J. A. Doukas, and H. Gonenc (2011), "Family Control and Financing Decisions." European Financial Management 17 (5), 860- 897.

Cronqvist, H. and M. Nilsson (2003). "Agency Costs of Controlling Minority Shareholders." The Journal of Financial and Quantitative Analysis, 38: 695 - 719.

Danes, S.M., Stafford, K., Haynes, G., and Amarapurkar, S. (2009). "Family capital of family firms: Bridging human, Social, and financial capital," Family Business Review, 22 (3), 199-215.

Danes, S.M., and Brewton, K.E. (2012). "Follow the capital: Benefits of tracking family capital across family and business systems." In Carsrud, A. L. and M. Brännback (Eds.), Understanding Family Businesses. Undiscovered Approaches, Unique Perspectives, and Neglected Topics, New York: Springer, $227-250$.

Dunne, T., S. D. Klimek, M. J. Robert, and D.I Y. Xu (2013). "Entry, Exit, and the Determinants of Market Structure". Rand Journal of Economics, 44, $462-487$.

Faccio, M. and L. H. P. Lang (2002), "The ultimate ownership of Western European corporations," Journal of Financial Economics, 365 - 395.

Fonseca, R., P. Michaud, and T. Sopraseuth (2007). Entrepreneurship, Wealth, Liquidity Constraints, and Start-Up Costs. IZA DP. No. 2874. IZA.

Fraser, S. (2012), Are entrepreneurs financially constrained? A new test based on finance gaps, CSME Working paper

Gaiotti, E. (2013), "Credit availability and investments: Lessons from the "Great Recession"," European Economic Review, 59, 212 - 227.

Gimeno ,J., T. B. Folta, A.C. Cooper and C. Y. Woo (1997). "Survival of the Fittest? Entrepreneurial Human Capital and the Persistence of Underperforming Firms." Administrative Science Quarterly, 42: 750 - 783.

Gompers, P., J. Ishii, and A. Metrick (2003). "Corporate Governance and Equity Prices." Quarterly Journal of Economics, 118: 107 - 155.

Gulbrandsen, T. (2005). "Flexibility in Norwegian Family-Owned Enterprises." Family Business Review, 18: 57 - 76.

Gulbrandsen, T. (2009). "Family businesses and trade unions." Economic and Industrial Democracy, 30: $592-613$..

Hempell, H. and C Sorenson (2010), The impact of supply constraints on bank lending in the Euro Area, crisis induced crunching?" ECB Working Paper Series 1262 November 2010.

Hetland, O. R. and A. Mjøs (2014), "Bankmarkedet for norske bedriftskunder gjennom o getter finanskrisen," Magma, 6, 2014, 70-78.

Hiebl, M. (2013). Risk taking in family firms: What do we really know? Journal of Risk Finance, 14(1), 49-70. 
Hurst, E. and A. Lusardi (2004). "Liquidity Constraints, Household Wealth and Entrepreneurship." Journal of Political Economy, 112: 319 - 47.

Hvide, H. and J. Møen (2010). "Lean and Hungry or Fat and Content? Entrepreneurs' Wealth and Start-Up Performance," Management Science, 56, 1242 - 1258.

Holmøy, A. (2013). Arbeids- og bedriftsundersøkelsen 2012. Dokumentasjonsrapport. Notater 38/2013. Oslo og Kongsvinger: Statistisk sentralbyrå.

Holth, B. A. (2003). Arbeids- og bedriftsundersøkelsen 2003. Dokumentasjonsrapport. Notater 66/2003. Oslo og Kongsvinger: Statistisk sentralbyrå.

Holtz-Eakin, D., D. Joulfaian, and H. S. Rosen (1994). "Sticking it Out: Entrepreneurial Survival and Liquidity Constraints." Journal of Political Economy, 102: 53 - 75.

Jensen, M. and W. Meckling (1976). "Theory of the firm: Managerial behaviour, agency costs, and ownership structure." Journal of Financial Economics, 3: $305-360$.

La Porta, R., F. Lopez-de-Silanes, and A. Shleifer (1999). "Corporate Ownership around the World.“ Journal of Finance, 54: 471 - 517.

Lyagoubi, M. (2006), "Family firms and financial behaviour: How family shareholders preferences influence firms' financing". In Poutziouris, P. , K. Smyrnios and S. Klein (Eds.), Handbook of Research on Family Businesses, 557 . Northampton, Mass.: Edward Elgar Publishing, 537 - 552.

McConaughy, D. L., M. C. Walker, G. V. Henderson jr., C. S. Mishra (1998). "Founding Family Controlled Firms: Efficiency and Value." Review of Financial Economics, 7: 1 19.

Morck, R. A. Shleifer and R. W. Vishny (1988). "Management Ownership and Market Valuation." Journal of Financial Economics, 20: 293 - 315.

Navaretti, G. B., R. Faini and A. Tucci (2008). Does Family Control Affect Trade Performance? Evidence for Italian Firms. CEP Discussion paper No 896. CEP.

Péres-Gonzáles, F. (2006). "Inherited Control and Firm Performance." American Economic Review, 96: 1559 - 1588.

Poutziouris, P. Z. (2006), "Structure and Performance of the UK family business PLC economy". In Poutziouris, P. , K. Smyrnios and S. Klein (Eds.), Handbook of Research on Family Businesses, 557 . Northampton, Mass.: Edward Elgar Publishing, 552 - 574.

Smith, B.F., and B. Amoako-Adu (1999), "Management Succession and financial performance of family controlled firms. " Journal of Corporate Finance, 5: $341-368$.

Stiglitz, J. E. and A. Weiss (1981), "Credit Rationing in Markets with Imperfect Information," American Economic Review, 71/3, 333 - 421.

Torp, H. (ed.)(2005). Nytt arbeidsliv. Medvirkning, inkludering og belønning. Gyldendal Akademisk.

Villalonga, B. and R. Amit (2005). "How do family ownership, control and management affect firm value." Journal of Financial Economics, 80: $385-417$.

Wilson, N. M. Wright and L. Scholes (2013), "Family Business Survival and the Role of Boards," Entrepreneurship Theory and Practice, 37, 1369 - 1289. 
Table 1 Family ownership and performance in Norway before the financial crisis (2003)

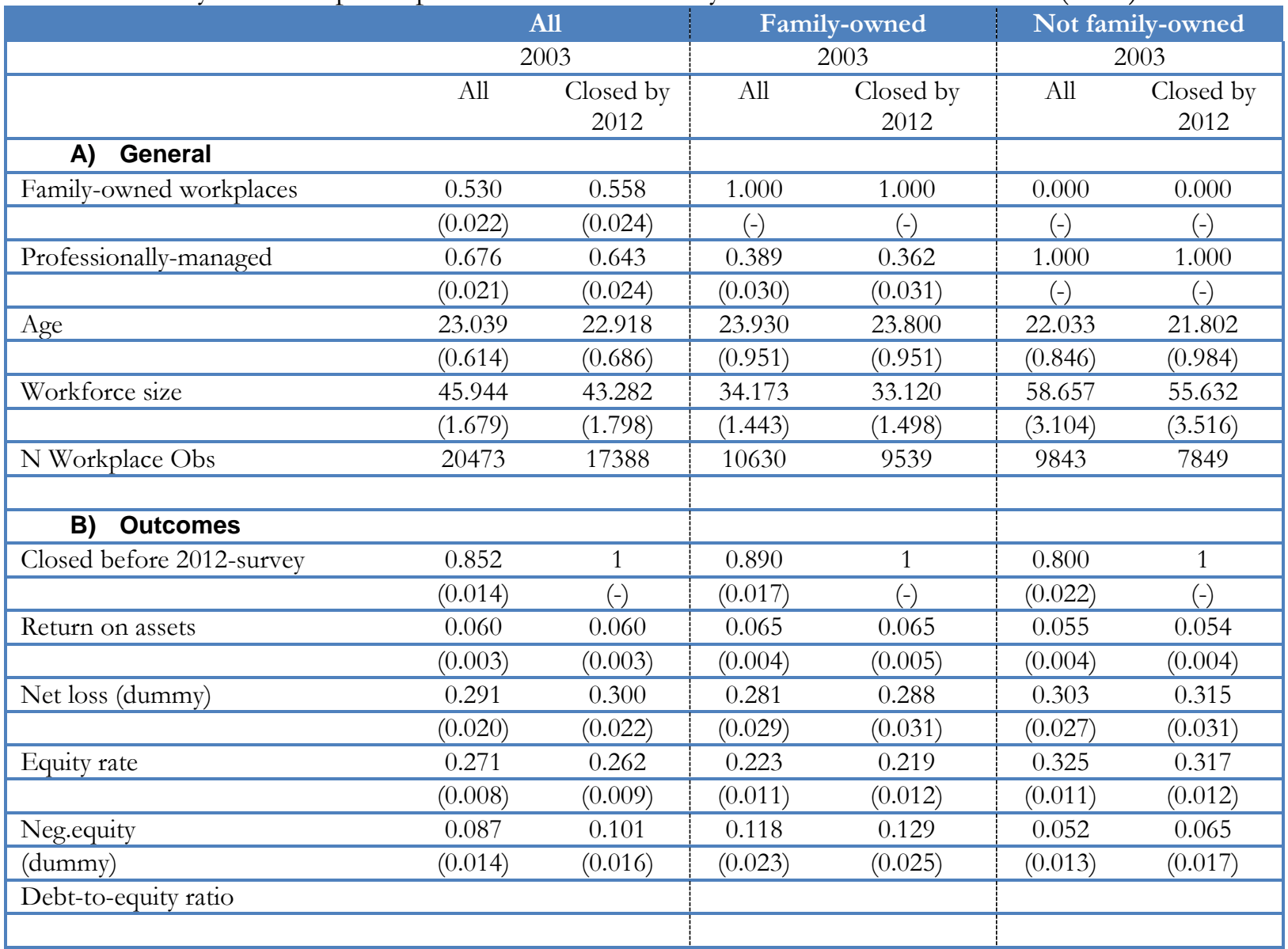

Note: Private sector workplaces only. Source: Norwegian Workplace and Employment Relations Surveys 2003 and 2012, linked to register data. The figures are representative for the population of private sector workplaces owned by limited firms with more than 10 employees. Estimated standard errors of the means are reported in parentheses. 
Table 2 Family ownership and performance in Norway before the financial crisis.

\begin{tabular}{|c|c|c|c|c|c|c|}
\hline & $\begin{array}{l}\text { Return on } \\
\text { assets }\end{array}$ & $\begin{array}{l}\text { Operating } \\
\text { loss }\end{array}$ & $\begin{array}{l}\text { Equity } \\
\text { rate }\end{array}$ & $\begin{array}{c}\text { Negative } \\
\text { shareholders' } \\
\text { value }\end{array}$ & $\begin{array}{l}\text { Debt-to- } \\
\text { equity ratio }\end{array}$ & $\begin{array}{l}\text { Current } \\
\text { asset-to- } \\
\text { debt }\end{array}$ \\
\hline & Model 1 & Model 2 & Model 3 & Model 4 & Model 5 & Model 6 \\
\hline \multicolumn{7}{|l|}{ Panel A) } \\
\hline \multirow[t]{2}{*}{ Family } & $0.010^{*}$ & $-0.064^{*}$ & $-0.036^{* *}$ & 0.024 & $0.472^{* *}$ & -0.022 \\
\hline & $(0.004)$ & $(0.041)$ & $(0.010)$ & $(0.024)$ & $(0.160)$ & $(0.029)$ \\
\hline \multicolumn{7}{|l|}{ Panel B) } \\
\hline \multirow[t]{2}{*}{ Family } & 0.008 & -0.064 & -0.011 & 0.010 & 0.256 & 0.027 \\
\hline & $(0.010)$ & $(0.048)$ & $(0.018)$ & $(0.031)$ & $(0.178)$ & $(0.036)$ \\
\hline \multirow[t]{2}{*}{ Family-manager } & 0.004 & -0.044 & $-0.044^{* *}$ & $0.053^{\mathrm{x}}$ & $0.377^{x}$ & $-0.083^{*}$ \\
\hline & $(0.006)$ & $(0.055)$ & $(0.027)$ & $(0.032)$ & $(0.225)$ & $(0.041)$ \\
\hline \multicolumn{7}{|c|}{ Additional controls in all panels $(A, B, C)$ :dummies for listed, export, size(4), industry(40), product demand(2), age (5) } \\
\hline Predicted baseline & 0.082 & 0.343 & 0.315 & 0.073 & 3.885 & 0.984 \\
\hline $\mathrm{N}$ & 1124 & 1124 & 1124 & 1124 & 1124 & 1124 \\
\hline Method: & Tobit & Probit & Tobit & Probit & Tobit & Tobit \\
\hline
\end{tabular}

Note: The table reports marginal effects. Dependent variable denoted by column head. Private sector limited workplaces only. Source: Duration panel, year 2003 only. Additional controls for the estimates: Workplace size dummies (11-20, 21-50, 51-100), product demand dummies (increased product demand, price elastic product demand) and dummies for 2-digit NACE industry code. Each observation is weighted by the inverse of the sampling probability of the workplace adjusted for no-response. Firm-cluster adjusted robust standard errors are reported in parentheses. ${ }^{* *},{ }^{*}$ and ${ }^{x}$ denote 1,5 and 10 percent level of significance, respectively. Full regression results available upon request. 
Table 3 The survival of workplaces and relationship to family ownership, performance and capital structure in Norway

\begin{tabular}{|c|c|c|c|c|c|c|c|}
\hline & Model 1 & Model 2 & Model 3 & Model 4 & Model 5 & Model 6 & Model 7 \\
\hline \multirow[t]{2}{*}{ Family and age $\leq 6(\mathrm{FY})$} & -0.587 & -0.717 & -0.826 & -0.692 & -0.677 & -1.104 & -0.657 \\
\hline & $(0.653)$ & $(0.719)$ & $(0.663)$ & $(0.652)$ & $(0.653)$ & $(0.914)$ & $(0.658)$ \\
\hline \multirow[t]{2}{*}{ Family and age $>6(\mathrm{FO})$} & $-0.593^{* *}$ & $-0.720^{* *}$ & $-0.769^{* *}$ & $-0.755^{*}$ & $-0.755^{*}$ & -0.400 & $-0.595^{*}$ \\
\hline & $(0.212)$ & $(0.220)$ & $(0.269)$ & $(0.703)$ & $(0.296)$ & $(0.330)$ & $(0.266)$ \\
\hline \multirow[t]{2}{*}{ FO X 2009} & $1.062^{*}$ & $0.962^{*}$ & $1.217^{*}$ & $1.241^{*}$ & $1.293^{*}$ & $1.379^{*}$ & $1.303^{* *}$ \\
\hline & $(0.487)$ & $(0.490)$ & $(0.508)$ & $(0.508)$ & $(0.528)$ & $(0.545)$ & $(0.510)$ \\
\hline \multirow[t]{2}{*}{ Net loss } & & & $1.005^{* *}$ & $0.618^{x}$ & $0.660^{*}$ & $0.620^{*}$ & $0.982^{* *}$ \\
\hline & & & $(0.257)$ & $(0.323)$ & $(0.307)$ & $(0.303)$ & $(0.272)$ \\
\hline \multirow[t]{2}{*}{ Net lossXfamily } & & & $-0.885^{* *}$ & $-0.962^{*}$ & $-0.995^{*}$ & $-0.983^{*}$ & $-0.876^{*}$ \\
\hline & & & $(0.418)$ & $(0.424)$ & $(0.429)$ & $(0.422)$ & $(0.472)$ \\
\hline \multirow[t]{2}{*}{ Neg.equity } & & & -0.580 & 0.143 & -0.435 & -0.119 & $-2.695^{*}$ \\
\hline & & & $(0.685)$ & $(0.887)$ & $(0.686)$ & $(0.868)$ & $(1.099)$ \\
\hline \multirow[t]{2}{*}{ Neg.equityXfamily } & & & $2.246^{* *}$ & $2.021^{*}$ & $2.343^{* *}$ & $2.372^{* *}$ & $4.479^{* *}$ \\
\hline & & & $(0.801)$ & $(0.809)$ & $(0.810)$ & $(0.801)$ & $(1.284)$ \\
\hline \multirow[t]{2}{*}{ Return on assets } & & & & $-4.702^{* *}$ & $-4.821^{* *}$ & $-4.925^{* *}$ & \\
\hline & & & & $(1.884)$ & $(1.828)$ & $(1.836)$ & \\
\hline \multirow[t]{2}{*}{ Equity ratio } & & & & 1.275 & 1.131 & 1.116 & \\
\hline & & & & $(1.256)$ & $(1.205)$ & $(1.216)$ & \\
\hline \multirow[t]{2}{*}{ Debt-to-equity ratio } & & & & 0.048 & 0.048 & 0.046 & \\
\hline & & & & $(0.081)$ & $(0.078)$ & $(0.078)$ & \\
\hline \multirow{2}{*}{ Net loss XNeg.equity } & & & & & & & $2.545^{* *}$ \\
\hline & & & & & & & $(1.181)$ \\
\hline \multirow[t]{2}{*}{ Net loss XNeg.equity Xfamily } & & & & & & & $-2.553^{* *}$ \\
\hline & & & & & & & $(1.438)$ \\
\hline \multirow[t]{2}{*}{ FO X 2008} & & & & & 0.928 & & \\
\hline & & & & & $(0.768)$ & & \\
\hline \multirow[t]{2}{*}{ FO X 2010} & & & & & -0.136 & & \\
\hline & & & & & $(0.652)$ & & \\
\hline \multirow[t]{2}{*}{ Family manager(FM) } & & & & & & 0.712 & \\
\hline & & & & & & $(1.037)$ & \\
\hline \multirow[t]{2}{*}{ FM X FO } & & & & & & -1.232 & \\
\hline & & & & & & $(1.104)$ & \\
\hline \multirow[t]{2}{*}{ FM X FO X2009 } & & & & & & -0.552 & \\
\hline & & & & & & $(0.721)$ & \\
\hline \multirow[t]{2}{*}{ Age 1-6 years } & $-3.508^{* *}$ & $-3.330^{* *}$ & $-3.943^{* *}$ & $-4.015^{* *}$ & $-3.762^{* *}$ & $-3.509^{* *}$ & $-3.869^{* *}$ \\
\hline & $(0.548)$ & $(0.755)$ & $(0.751)$ & $(0.941)$ & $(0.790)$ & $(0.787)$ & $(0.699)$ \\
\hline Age $7-14$ years & $-4.297^{* *}$ & $-4.010^{* *}$ & $-4.679^{* *}$ & $-4.779^{* *}$ & $-4.512^{* *}$ & $-4.264^{* *}$ & $-4.664^{* *}$ \\
\hline & $(0.421)$ & $(0.707)$ & $(0.742)$ & $(0.869)$ & $(0.780)$ & $(0.768)$ & $(0.684)$ \\
\hline Age 15-19 years & $-4.464^{* *}$ & $-4.314^{* *}$ & $-4.974^{* *}$ & $-5.085^{* *}$ & $-4.807^{* *}$ & $-4.569^{* *}$ & $-4.826^{* *}$ \\
\hline & $(0.455)$ & $(0.802)$ & $(0.844)$ & $(0.958)$ & $(0.877)$ & $(0.887)$ & $(0.695)$ \\
\hline Age $20-26$ years & $-4.218^{* *}$ & $-4.094^{* *}$ & $-4.661^{* *}$ & $-4.760^{* *}$ & $-4.505^{* *}$ & $-4.278^{* *}$ & $-4.561^{* *}$ \\
\hline & $(0.478)$ & $(0.754)$ & $(0.765)$ & $(0.910)$ & $(0.790)$ & $(0.793)$ & $(0.650)$ \\
\hline Age $27-35$ years & $-4.286^{* *}$ & $-4.102^{* *}$ & $-4.577^{* *}$ & $-4.695^{* *}$ & $-4.442^{* *}$ & $-4.179^{* *}$ & $-4.544^{* *}$ \\
\hline & $(0.496)$ & $(0.673)$ & $(0.700)$ & $(0.929)$ & $(0.755)$ & $(0.751)$ & $(0.660)$ \\
\hline Age $36-47$ years & $-4.134^{* *}$ & $-4.935^{* *}$ & $-4.442^{* *}$ & $-4.583^{* *}$ & $-4.317^{* *}$ & $-4.085^{* *}$ & $-4.396^{* *}$ \\
\hline & $(0.421)$ & $(0.682)$ & $(0.705)$ & $(0.865)$ & $(0.740)$ & $(0.731)$ & $(0.629)$ \\
\hline Listed & 0.159 & 0.331 & 0.370 & 0.380 & 0.377 & 0.387 & 0.214 \\
\hline & $(0.286)$ & $(0.306)$ & $(0.299)$ & $(0.310)$ & $(0.310)$ & $(0.310)$ & $(0.290)$ \\
\hline ListedX2009 & $1.223^{*}$ & $1.213^{x}$ & $1.341^{*}$ & $1.352^{*}$ & $1.357^{*}$ & $1.181^{\mathrm{x}}$ & $1.341^{*}$ \\
\hline & $(0.577)$ & $(0.628)$ & $(0.611)$ & $(0.621)$ & $(0.621)$ & $(0.645)$ & $(0.590)$ \\
\hline Export & -0.156 & -0.129 & -0.223 & -0.265 & -0.270 & -0.298 & -0.304 \\
\hline & $(0.285)$ & $(0.365)$ & $(0.361)$ & $(0.366)$ & $(0.364)$ & $(0.355)$ & $(0.341)$ \\
\hline ExportX2009 & $1.029^{\mathrm{x}}$ & 0.907 & $1.049^{\mathrm{x}}$ & $1.018^{x}$ & $1.028^{x}$ & 0.817 & $1.072^{\mathrm{x}}$ \\
\hline
\end{tabular}




\begin{tabular}{|lccccccc|}
\hline & $(0.569)$ & $(0.608)$ & $(0.581)$ & $(0.581)$ & $(0.588)$ & $(0.540)$ & $(0.572)$ \\
\hline Additional controls: & & & & & & & \\
\hline Year dummies(9) & Yes & Yes & Yes & Yes & Yes & Yes & Yes \\
\hline $\begin{array}{l}\text { Size dummies(4), market/ } \\
\text { industry dummies (10) }\end{array}$ & & Yes & Yes & Yes & Yes & Yes & Yes \\
\hline Log pseudo L & -21239 & -19894 & -19137 & -18958 & -18931 & -18866 & -19728 \\
\hline N & 9750 & 9597 & 9597 & 9597 & 9597 & 9597 & 9597 \\
\hline
\end{tabular}

Note: Method: Complementary Log-Log duration regressions (age). Private sector limited workplaces only. Source: Norwegian Workplace and Employment Relations Survey 2003 linked to the Accounting register. Capital loss implies Own capital Additional controls for the estimates: Workplace size dummies (11-20, 21-50, 51-100), market dummies (increased product demand, price elastic product demand) and dummies for 1-digit NACE industry code (8). Each observation is weighted by the inverse of the sampling probability of the workplace adjusted for noresponse. Firm-cluster adjusted robust standard errors are reported in parentheses. ${ }^{* *},{ }^{*}$ and $\mathrm{x}$ denote 1,5 and 10 percent level of significance, respectively. Full regression results available upon request. 
Figure 1 Lending, bankruptcies and workplace exit in Norway

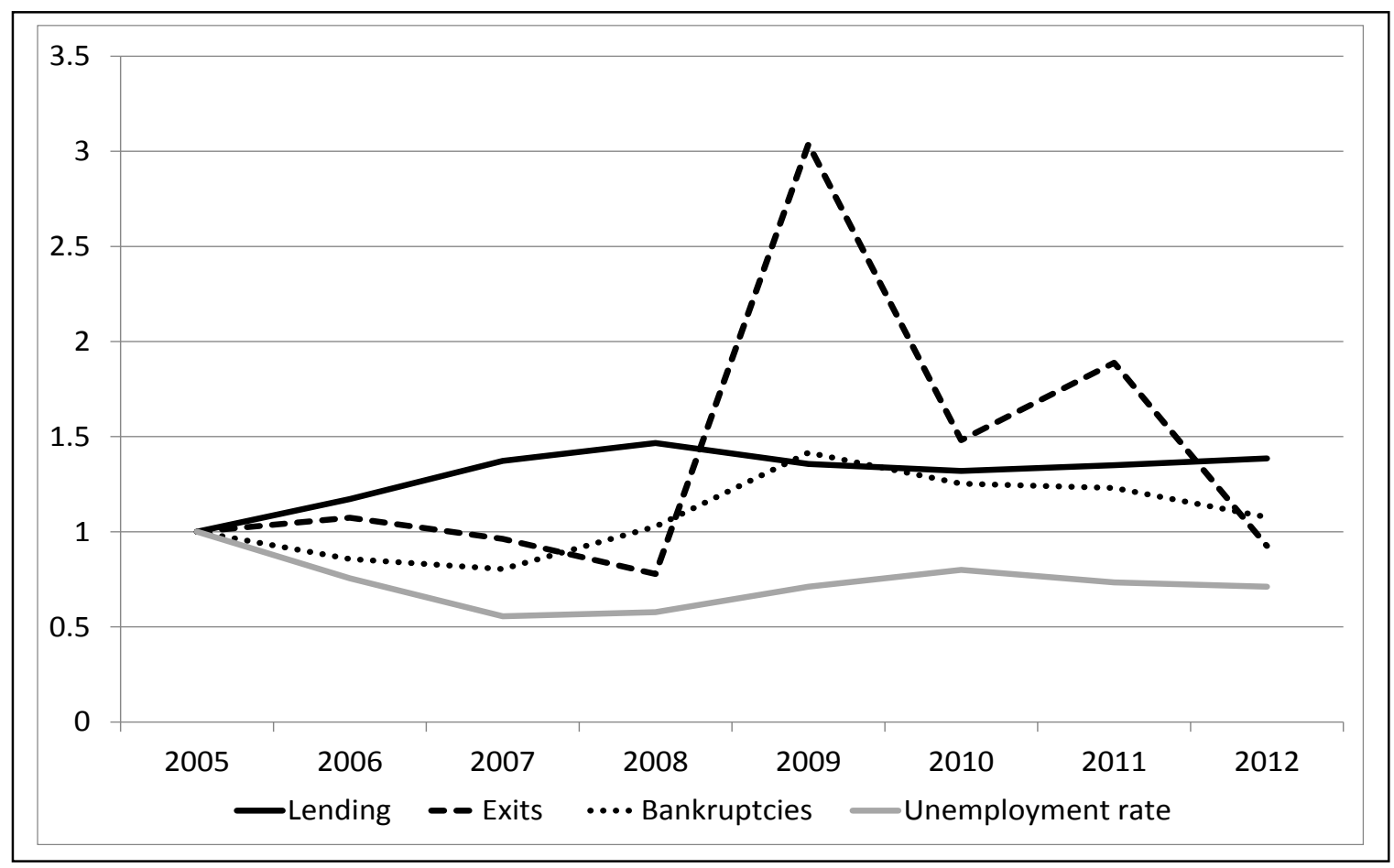

Note: Source: Statistics Norway for lending, bankruptcies and unemployment figures, own data on workplace exit rates for limited firms (based on population-wide job data collected from the national welfare authority). All values normalized to 1 in 2005 (measured relative to 2005-values). 
Figure 2 Closure rates for NWERS-2003 workplaces over time contingent on survival (hazard).

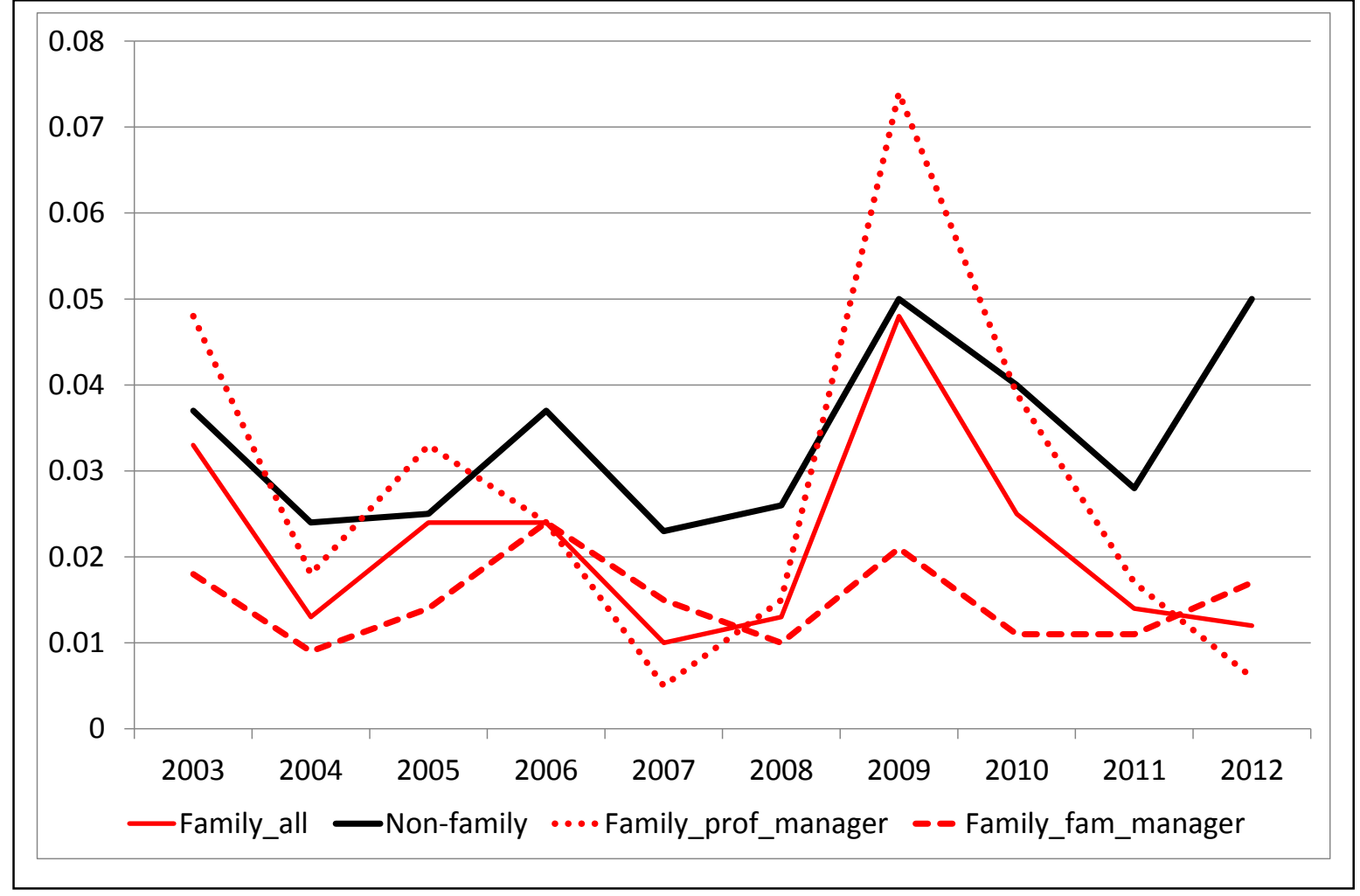


Figure 3 Predicted hazard rates for family and non-family businesses before and during the financial crisis.

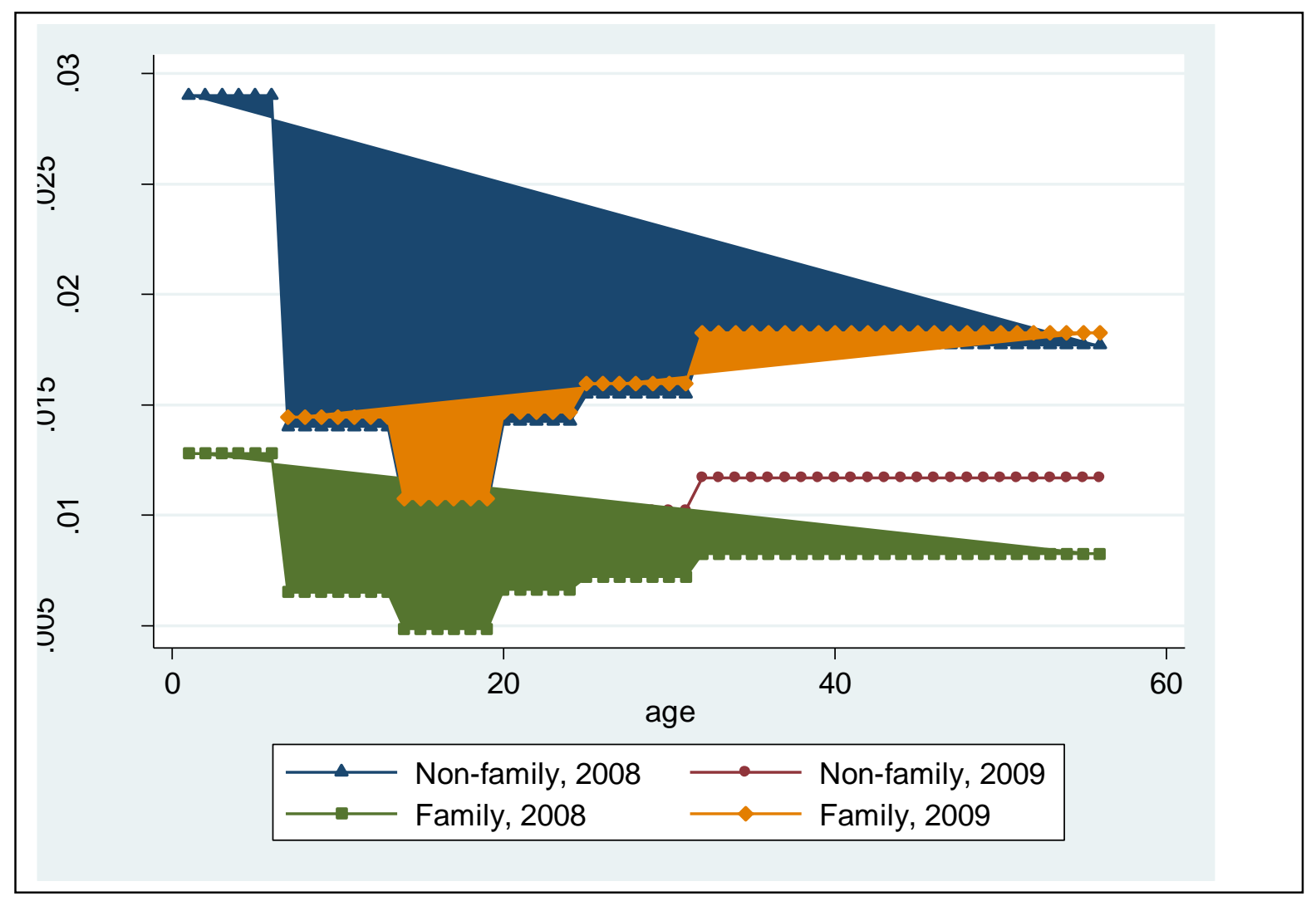

Note: The hazard rates are predicted based upon Model 3 of Table 3. 
Figure 4 Predicted cumulative survival probabilities for family and non-family businesses before and under the financial crisis.

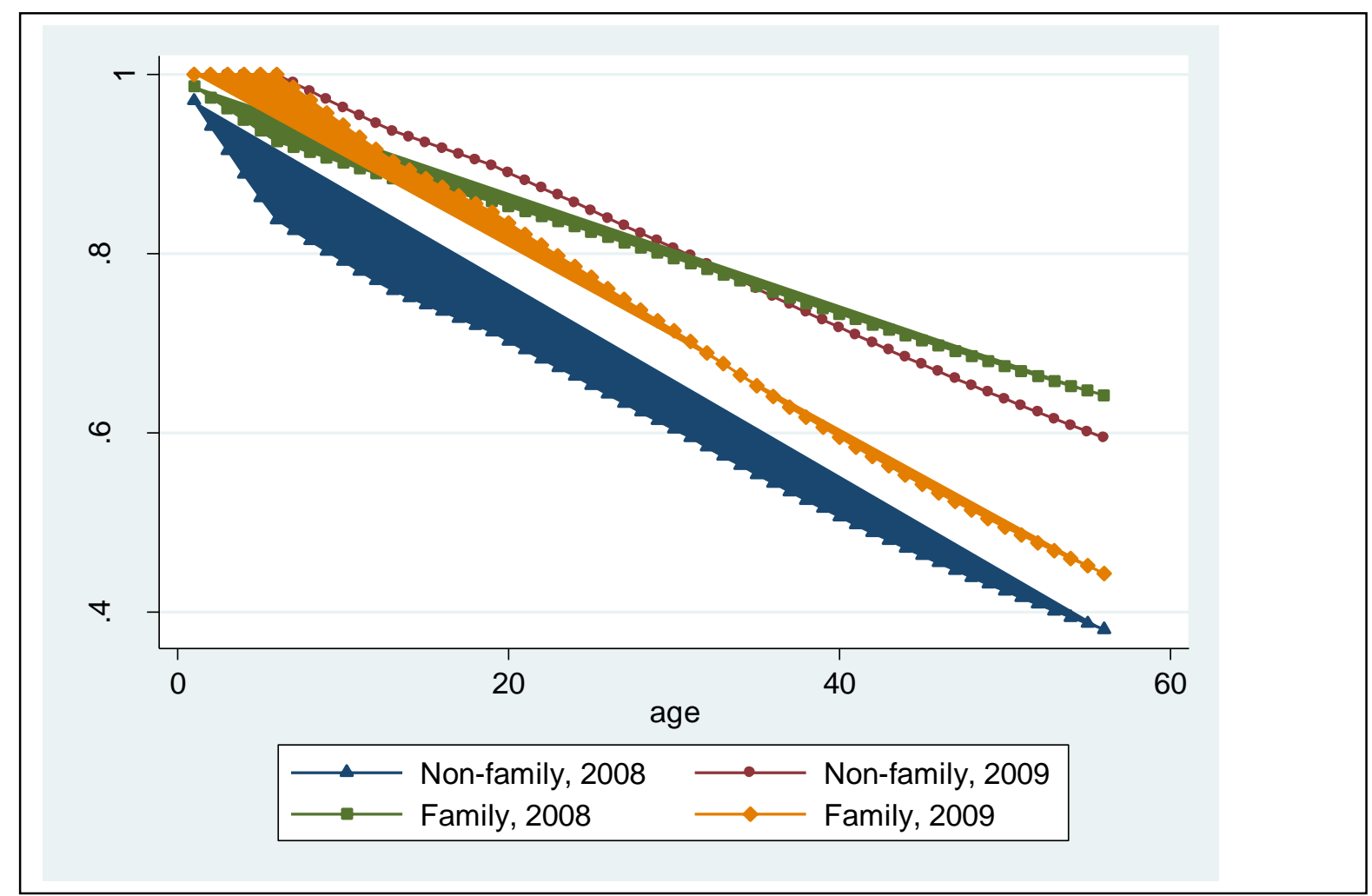

Note: The cumulative survival rates are predicted based upon Model 3 of Table 3. 